PRODUCTION

ENGINEERING

ARCHIVES
2015, Vol. 9, No 4, pp 26 - 29

ISSN 2353-5156

ISSN 2353-7779 (print version)

(online version)

\title{
Games Learning in education for a newly accredited study course: Fundamentals of Industrial Engineering
}

\author{
Rastislav Beňo ${ }^{1}$, Petra Marková2 ${ }^{2}$ Vanessa Prajová ${ }^{3}$, Helena Makyšová ${ }^{4}$ \\ 1,2,3 Ing., PhD.,Slovak University of Technology in Bratislava, Faculty of Materials Science and Technology in Trnava, Institute of Industrial \\ Engineering and Management, Paulínska 16, 917 24, Trnava, Slovak republic, rastislav.beno@stuba.sk, petra.markova@stuba.sk, \\ vanessa.prajova@stuba.sk \\ 4 Assoc. prof., Ing., PhD.,Slovak University of Technology in Bratislava, Faculty of Materials Science and Technology in Trnava, Institute \\ of Industrial Engineering and Management, Paulínska 16, 917 24, Trnava, Slovak republic, helena.makysova@stuba.sk
}

\begin{abstract}
In the EU, the quality of education in recent years has become a priority topic. In the context of university education and meeting the requirements of industrial practice, in the countries of the EU, different activities are carried out. These activities are focused on the techniques and methods by which we can achieve excellence in the educational process, creative solutions and innovative forms. The aim is to adapt educational processes to the current digital age. Therefore, in the educational process it is necessary to apply new forms and methods of education. With application of this method we can streamline the educational process and also increase the initiative and interest of students in acquiring new knowledge, skills and abilities. The aim of the article is to present the project, which is focused on improving the educational process by using a new approach to learning - Games Learning
\end{abstract}

Key words: games learning, accreditation, industrial

\section{Introduction}

Scholars from various disciplines have recently shown increasing interest in using well-designed digital games to support learning (e.G., GEE, 2003 ; PRENSKY, 2006 ; SHAFFER, SQuire, HALVERSON, \& GeE, 2005 ; SHUTE, RIEBER, \& VAN ECK, 2011 ). A common motivation for studying games as vehicles to support learning is frustration with the current education system and a desire for alternative ways of teaching - ways that increase student engagement and yield a rich, authentic picture of the student(s).
The key area of education in Slovakia is college preparation and the content is as close as possible to the needs of company practice and requirements of the labor market in order to provide the best education and the best possible job placement.

An example of this is the active participation of the Faculty of Materials Science and Technology (FMST) into the national project "Vysoké školy ako motory rozvoja vedomostnej spoločnosti (CVTI SR 2013). Likewise, the efforts by the FMST for a revision of the knowledge status in the value faculty hierarchy and developing innovative forms of transfer of $\mathrm{R} \& \mathrm{D}$ and 
education, for example through the "Knowledge-based Faculty for economic practice (REŠETOVÁ 2013)".

In previous years the Institute of Industrial Engineering and Management solved a project aimed at rationalizing and improving the study program Industrial Management to support career counseling following a European initiative agenda for new job skills (EC 2013).

College education in the field of Industrial Engineering could be aimed at preparing industrial engineers and managers, who in accordance with the profiles of graduates would be able to apply to different levels of management in economic practice, would be able to adjust flexibly to the requirements of the labor market and would be able to apply the knowledge gained by study.

It follows the importance of knowledge and the use of methods, techniques and tools selected fields of industrial engineering (quality, production, logistics, ergonomics and human factors) in industrial enterprises. Experiences, expertise and knowledge in the mentioned areas would help to solve unexpected problems and risks and related changes in industrial engineering. The possibility to effectively acquire knowledge of these areas allows to apply the Games Learning (GL) in a new subject education "Basics of Industrial Engineering".

\section{Aim \& methodology}

The project aim is to ensure the improvement of the education process using a new approach to education - GL. The aim is based on the current society-wide requirement to improve education at universities through the introduction of new and innovative forms to the education process in accordance with practice requirements. The present project is based on the intention to develop new technologies, methods and forms of education and training with the targetoriented development of theoretical knowledge in industrial engineering area including the possibilities and conditions for their application in the educational process. Methods and tools that are in terms of theory and application in practice appear to be relatively complex, would be processed for the industrial engineering field with a focus on optimization process of production management, logistics, quality processes as well as the standardization and work streamlining through training games with the application of the principles learning by doing for support the education of students of technical university.

The main objective of the project: Development and improvement of the educational process through the application GL in a new accredited subject: Basics of Industrial Engineering can be pursued through the fulfillment of partial objectives within a defined procedure:

$>$ to define key pedagogical and scientific - research employees focused on technical specialization field of study.

$>$ Define key pedagogical and scientific - research employees aimed at technical field of study Industrial Engineering, respectively a similar or related field based on qualifications, composition and homogeneity of the team in terms of professional orientation and inclusion;

$>$ Specify selected activities in the various fields of Industrial Engineering in accordance with the content focus to the Industrial Engineering field of study;

$>$ Analyze the current state of requirements in business practice in the field of tools, methods and techniques application in selected industries to identify the required knowledge, skills and abilities of graduates in the Industrial Engineering field of study;

$>$ Prepare the study material of selected methods from Industrial Engineering field of study (e. g. with focus on production processes optimization, work standardization; work efficiency; Lean principles understanding; revealing the potential for improving the efficiency equipment; solutions for failures simulate etc.) with application of concrete tools, methods and techniques through training games;

$>$ Apply knowledge and skills in educational process of the new accredited study subject: Basics of Industrial Engineering;

$>$ Realize the research of GL applications impact into the educational process effectiveness in a newly accredited study course: Fundamentals of Industrial Engineering in contrast to classical educational techniques in the educational process. 
To reach the main objective the GL approaches for selected industrial engineering field will be used, as shown in the following Table 1.

Table 1 Games Learning training games and training materials

\begin{tabular}{|l|l|}
\hline \multicolumn{2}{|c|}{ Training games and Training materials } \\
\hline \multirow{3}{*}{ Training games } & $\begin{array}{l}\text { CEZ (OEE); World of Innovations; 5S; } \\
\text { Steam Machine, SMED; MSA; Technic - } \\
\text { Lean production and logistics. }\end{array}$ \\
\hline \multirow{5}{*}{ Training materials } & $\begin{array}{l}\text { Standardization methodology; 5S - clean } \\
\text { and organized workplace; SMED; Introduc- } \\
\text { tion to TPM; OEE; Autonomous mainte- } \\
\text { nance, Process improvement in maintenance, } \\
\text { planned and preventive maintenance, Options } \\
\text { for improving the organization of work }\end{array}$ \\
\hline
\end{tabular}

Source: Own study

The project is a goal - orientated so that it is possible to educate future industrial engineers who are according to Košturiak (2007) able to design; implement; plan and manage complex integrated production systems and systems for provision services and secure their high performance; reliability and managing cost related to them.

Students will be able to actively work with industrial engineering methods among which the Avallone, Baumeister \& Sadegh (2007)is included: process analysis; workplace design; elements of motion and time study; work measurement; job standardizing and performance rating.

\section{Project schedule and project activities}

Activities to meet the main objective are characterized by providing the necessary courses and training materials for GL, received training on a training selected complex game, application training games into practical learning process and quality evaluation of the education process through research and standard methods of evaluation of successful objects. The management and implementation of the project will be drawing lessons from the education process, scientific and research activities and experience of individual members of the team. The project objectives are designed so that the maximum use of applied and relevant experience, knowledge and individual team member skill. The sub-project tasks will be conducted by the competent members of the team in schedule terms as follows:
$>$ tasks allocation to individual members of the research team (provided by project leader),

$>$ project management during the implementation (to be coordinated by the project manager),

$>$ acquisition, processing and analysis necessary data for solving the tasks given to the project (all members of the research team),

$>$ documents processing for the creation of study material (all members of the research team),

$>$ outcomes implementation in the educational process in the field of Industrial Engineering (all members of the research team),

$>$ the research execution impact applications GL the effectiveness of the educational process (all members of the research team),

$>$ the impact evaluate of research applications GL the effectiveness of the educational process (all members of the research team).

\section{Discussion}

The target group for the project are students from the study program Industrial Management, who will be actively involved in the educational process through the application of GL.

The main project benefit consists in applying new approaches in the field of education through training games with learning by doing application for supporting effective education of students of the Technical University. Students from Industrial Management study program will acquire knowledge with creative form so they will be able to efficiently and easily apply their knowledge in economic practice and the automotive industry. Students will learn to understand the concepts and functioning approaches and tools such as Andon, Chaku -Chaku, Genchi Genbutsu, Heijunka, Jidoka a etc. (LEI 2008).

\section{Summary and conclusions}

Students will be actively involved in the educational process during the application of tools and industrial engineering methods, such as CEZ, SMED, 5S and lean manufacturing, which are effectively applied in the automotive field. Via the Games Learning students will be able to recognize and be able to apply 
Key Success Factors, as stated by (ZANDIN 2001), 'Be Flexible, but Focused, Apply Industrial Engineering Concepts to Real - World Problems, Understand the "Big Picture" - How Change Initiatives Impact the Overall Organization, Understand and Analyze the Current Process Accurately, Manage Change, Follow Throughput of Implementation, Be creative, Communicate Clearly'.

\section{Additional information}

This article was supported by project VEGA Nr. 1/0448/13 "Transformation of ergonomics program into the company management structure through integration and utilization QMS, EMS, HSMS."

This article was supported also by project $\mathrm{Nr}$. 087/15_RT “The research of Games Learning applications impact into the educational process effectiveness in newly accredited study course: Fundamentals of Industrial Engineering". The project is co-funded by the Volkswagen Slovakia Foundation from the grant program "to Develop Nadácia Volkswagen Slovakia Technique“.

\section{Literature}

1. Avallone E., Baumeister T., SAdegh M A. 2007. Marks' Standard Handbook for Mechanical Engineering, R. R. Donnelley \& Sons Company, Chicago, ISBN 978-0-07-142867.5

2. BORKOWSKI S. 2014: Employees satisfaction innovative approach - pp. 39-44, Production Engineering Archives Vol. 3, No. 2 (2014), ISSN 2353-7779

3. CVTI SR, National project: Universities as Engines of Knowledge - based Society [on-line], Available at: http://vysokoskolacidopraxe.sk/sk/, [cit. 201529-09]

4. D. Ifenthaler Et AL. 2012 (eds.), Assessment in Game-Based Learning: Foundations, 43 Innovations, and Perspectives, DOI 10.1007/978-1-46143546-4_4, (C) Springer Science+Business Media New York 2012
5. EUROPEAN COMISSION. New Skills for New Jobs, Available at:http://ec.europa.eu/social/ main.jsp?langId=en\&catId=822, [cit. 2015-29-09]

6. GEE, J. P. (2003).: What digital games have to teach us about learning and literacy. New York: Palgrave Macmillan.literacy . New York: Palgrave Macmillan.

7. INGALDI M. 2015:- Sustainability as an element of environmental management in companies - pp. 2932, Production Engineering Archives Vol. 7, No. 2 (2015), ISSN 2353-7779

8. KNOP K. 2015:Statistical analysis of responses concerning the importance of human and production or services issues in various companies - pp. 40-44, Production Engineering Archives Vol. 7, No. 2 (2015), ISSN 2353-7779

9. LEAN ENTERPRISE INSTITUTE, 2008. Lean Lexicon a graphical glossary for Lean Thinkers, The Lean Enterprise Institute, Inc., Cambridge, ISBN 09667843-6-7

10. PRensky, M. (2006). Don't bother me mom, I'm learning!: How computer and digital games are preparing your kids for 21st century success and how you can help! St. Paul, MN: Paragon House.

11. REŠETOVÁ K. 2013. Knowledge management system of monitoring instruments of the graduates' employment within the integration into the $E U$, Available at: http://www.mtf.stuba.sk/english/ divisions/division-of-knowledge-management /projects.html?page_id=7178, [cit. 2015-29-09]

12. SAlvendy G. 2007. Handbook of Industrial Engineering: Technology and Operations Management, Third Edition, U.S.A. ISBN 9780471-33057-8

13. Shaffer, D. W., SQuire, K. A., Halverson, R., \& GEE, J. P. (2005). Digital games and the future of learning. Phi Delta Kappan, 87 (2), 104-111.

14. SHUTE, V. J., RIEBER, L., \& VAN ECK, R. (2011). Games and learning. In R. Reiser \& J. Dempsey (Eds.), Trends and issues in instructional design and technology (3rd ed., pp. 321-332). Upper Saddle River, NJ: Pearson Education.

15. Ulewicz R., VaŠKo A., KlimecKA-TATAR D. 2014: - Controlling of the logistic processes - pp. 26-30, Production Engineering Archives Vol. 3, No. 2 (2014), ISSN 2353-7779

16. ZANDIN, B. K. 2001. Maynard's Industrial Engineering Handbook, Fifth Edition, McGrawHill: New York, ISBN 978-0-07-041102-9 